\begin{tabular}{|l|l|l||}
\hline \multicolumn{2}{|c|}{ PublisherInfo } \\
\hline \hline PublisherName & $:$ & BioMed Central \\
\hline \hline PublisherLocation & $:$ & London \\
\hline \hline PublisherImprintName & $:$ & BioMed Central \\
\hline \hline
\end{tabular}

\title{
Implications of angiogenic heterogeneity
}

\begin{tabular}{|l|l|l||}
\hline \multicolumn{2}{|c||}{ ArticleInfo } \\
\hline \hline ArticleID & $:$ & 8 \\
\hline \hline ArticleDOI & $:$ & $10.1186 /$ ar-2000-66808 \\
\hline \hline ArticleCitationID & $:$ & 66808 \\
\hline \hline ArticleSequenceNumber & $:$ & 4 \\
\hline \hline ArticleCategory & $:$ & Paper Report \\
\hline \hline ArticleFirstPage & $:$ & 1 \\
\hline \hline ArticleLastPage & $:$ & 3 \\
\hline \hline & $:$ & RegistrationDate : 2000-5-9 $: 2000-5-9$ \\
ArticleHistory & $:$ & OnlineDate \\
\hline \hline ArticleCopyright & $:$ & Current Science Ltd2000 \\
\hline \hline ArticleGrants & $:$ & \\
\hline \hline ArticleContext & $:$ & 130752211 \\
\hline \hline
\end{tabular}


Aff1 Center of Experimental Rheumatology, Switzerland

\section{Keywords}

Arthritis, C5,complement, gene-disruption, mouse

\section{Context}

In physiologic conditions, vascular endothelial cells rarely proliferate but remain differentiated and quiescent. This quiescence is the result of low levels of endothelial cell growth stimulators and high basal levels of inhibitors. In pathologic conditions, this stimulator to inhibitor ratio is disturbed by either favoring angiostatic factors (disorders with decreased angiogenesis, such as systemic sclerosis) or endothelial growth stimulators (disorders with enhanced angiogenesis, such as RA). To determine whether this angiogenic balance is genetically determined.

\section{Significant findings}

Compared to C57BL/6J mice, 3/16 strains of mice had a significantly lower angiogenic response in the corneal micropocket assay when $80 \mathrm{ng}$ bFGF was applied. A significant increase in neovascularization relative to that for C57BL/6J mice was observed in 15/21 strains when $10 \mathrm{ng}$ bFGF was applied. Analysis of vessel growth at different doses of bFGF revealed that the induced neovascularization area was linearly related to the amount of bFGF, with a maximum of $0.25 \mathrm{~mm} /$ day at $80 \mathrm{ng}$ in $\mathrm{C} 57 \mathrm{BL} / 6 \mathrm{~J}$ mice. In contrast, the $\mathrm{SJL} / \mathrm{J}$ strain reached a plateau at $0.15 \mathrm{~mm} /$ day for doses above $10 \mathrm{ng}$. As an example of strains with a high angiogenic susceptibility, 129/SvImJ mice produced a near maximal response of $0.25 \mathrm{~mm} /$ day with bFGF doses of only $10 \mathrm{ng}$. Interestingly, formation of hyphemas (as one marker of iris neovascularization) was found significantly more often in albino strains than in their related pigmented strain, indicating that factors linked to pigmentation/melanin produced an inhibitory influence on the angiogenic balance. Differences in the sensitivity between the 129 and C57BL/6J strains similar to the differences found for the bFGF experiments were found with VEGF induced corneal neovascularization. In line with the stimulation experiments, treatment with angiogenesis inhibitors resulted in an enhanced level of inhibition in 129/ReJ (high angiogenic susceptibility) and a lack of inhibition in $\mathrm{SJL} / \mathrm{J}$ mice. In vitro, aortic ring outgrowth of endothelial cells was significantly higher for samples from 129/ReJ mice than for C57BL/6J or SJL/J mice. The addition of growth factors (including bFGF and VEGF) caused a marked increase in endothelial sprouting from 
both the C57BL/6J and 129/SvImJ but not the SJL/J mice, similar to the blunted response in the corneal assay.

\section{Comments}

In this paper, Rohan et al provide evidence that the responsiveness of mouse endothelial cells to different angiogenic factors as well as to angiogenesis inhibitors is genetically determined. It has to be emphasized that it is too early to draw conclusions for humans from these mouse studies; however, the identification of genes that define and control the angiogenic potential may help to predict the clinical outcome of patients with disorders depending on angiogenesis, such as rheumatoid arthritis (RA). In addition, these factors may help to identify individuals who will be most sensitive to angiogenesis inhibitors in clinical trials. The finding that factors correlated with pigmentation exert inhibitory effects on angiogenesis is of particular interest as this may explain ethnic differences in disease manifestations. For example, the prevalence of systemic sclerosis in Afro-Americans is higher than in Caucasians and impaired angiogenesis is thought to play a major role in the early pathogenesis of this disease. Thus, it may be hypothesized that melanin-related factors shift the angiogenic balance to angiostatic factors, thereby increasing susceptibility to impaired angiogenesis in these patients.

\section{Methods}

Inbred strains of mice were examined for their vascular responsiveness using the cornea micropocket assay. Sucralfate pellets containing various concentrations of basic fibroblast growth-factor (bFGF) or vascular endothelial growth factor (VEGF) were implanted into the corneal stroma. The induced vascular response was assessed measuring the maximal vessel length and clock hours of neovascularization. The sensitivity to angiogenesis inhibitors was determined by injections of TNP-470 and thalidomide. For in vitro studies, the endothelial outgrowth from aortic rings taken from different mouse strains was assessed in the aortic ring assay with and without growth factor supplements.

\section{References}

1. Rohan RM, Fernandez A, Udagawa T, Yuan J, D`Amato RJ: Genetic heterogeneity of angiogenesis in mice. FASEB J. 2000, 14: 871-876.

This PDF file was created after publication. 